\title{
Growth, Yield and Nutrient Uptake Capacity of Rice under Different Sulphur Levels
}

\author{
A. K. M. Sajjadul Islam', Md. Shohel Rana ${ }^{2}$, Md. Mazibur Rahman², Md. Jainul Abedin Mian², \\ Md. Mezanur Rahman ${ }^{3 *}$, Md. Asif Rahman ${ }^{4}$, Nazmun Naher ${ }^{5}$
}

${ }^{1}$ Hybrid Rice Division, BRAC Agricultural Research and Development Centre, Gazipur 1701, Bangladesh

${ }^{2}$ Department of Soil Science, Bangladesh Agricultural University, Mymensingh 2202, Bangladesh

${ }^{3}$ Department of Agroforestry and Environment, Bangabandhu Sheikh Mujibur Rahman Agricultural University, Gazipur 1706, Bangladesh

${ }^{4}$ Department of Genetics and Plant Breeding, Bangabandhu Sheikh Mujibur Rahman Agricultural University, Gazipur 1706, Bangladesh ${ }^{5}$ Scientific Officer, PRRS, Bangladesh Agricultural Research Institute, Gazipur-1701, Bangladesh

A R T ICLE INFO

Article history:

Received 24 March 2016

Accepted 23 July 2016

Available online, ISSN: 2148-127X

Keywords:

Bangladesh

BRRI dhan 41

Fertilizing

Nutrient uptake

Productivity

${ }^{*}$ Corresponding Author:

E-mail: shaon_pstu@yahoo.com

A B S T R A C T

Because of using sulphur free fertilizer, rice crop facing tremendous sulphur (S) deficiency throughout the world as well as in Bangladesh. However, farmers of Bangladesh often overlook the importance of sulphur fertilization on rice yield. Therefore, the present study was conducted to investigate the influence of different levels of sulphur on growth, yield attributes and uptake of N, P, K and S by grain and straw of BRRI dhan 41 rice variety. The experiment was laid out in randomized complete block design with three replication and eight treatments including control. The result of the study revealed that the highest plant height, panicle length, filled grain was found in T1 (50\% RFD of S) treatment, while the utmost number of effective tiller and straw yield was recorded in T5 (150\% RFD of S) treatment. Interestingly, maximum grain yield as well as uptake of N, P, K and S by grain and straw was significantly higher in T6 (175\% RFD of S) treatment. The highest grain yield of T6 treatment might be due to maximum nutrient use efficiency. However, in all cases control treatment (T0) gave the worst result. The present study clearly indicates that higher rates (175\% of the recommended dose) of $\mathrm{S}$ along with other fertilizers may be recommended for better growth and yield of BRRI dhan41 in Bangladesh soil.

\section{Introduction}

Rice is the most important crop within the sector contributes for about $92 \%$ of the total food grains produced in the country. In respect of area and production of rice, Bangladesh ranks fourth following China, India and Indonesia (FAO, 2013). Currently, rice occupies 11.42 million hectares of land and overall production of rice is about 34.23 million tons (BBS, 2013). Nevertheless, the population of Bangladesh is growing by two million every year and may increase by another 30 million over the next 20 years. Thus, Bangladesh will require about 27.26 million tons of rice for the year 2020 (BRRI, 2011). During this time, total area under rice will also shrink to 10.28 million hectares. Under this circumstance, horizontal expansion of rice area is not possible (Abdullah et al., 2015). Hence, only one avenue left is to increase production of rice by vertical means through introduction of high yielding varieties and appropriate management practices (Islam et al., 2015; Sohel et al., 2016). Among the management practices, judicious use of sulphur fertilizer is the most important one.
Sulphur is an essential macronutrient nutrient for plants ranked $4^{\text {th }}$ after nitrogen, phosphorus and potassium because of its indispensable role in proteins synthesis, vitamins, enzyme and flavoured compounds in plant (Bera and Ghosh, 2015; Islam et al., 2016). About $90 \%$ of plant sulphur present in amino acid (methionine and cysteine) and a variety of metabolites (thiamine, thiamine, pyrophosphate, glucosinolates, glutathione and phytochelatins), which play a pivotal role in building blocks of protein, formation of chlorophyll, activation of enzymes etc. (Tewari et al., 2010; Hoefgen and Nikiforova, 2008). Furthermore, deficient supply of $S$ in soil causing lower uptake of nitrate hence retards the activity of nitrate reductase as well as $\mathrm{N}$ metabolism in plants (Prosser et al., 2001; Abdallah et al., 2010). In Bangladesh, sulphur deficit soils ranked third among problem soils, which is prominent in light-textured soils. About 3.95 million hectares of land are sulphur deficient, which represents approximately $16 \%$ of the total problem soils in Bangladesh (Huq and Shoaib, 2013). This area gradually increasing due to intensive agriculture practices, following multiple cropping systems in association with 
using of sulphur free fertilizer and no use of organic manures. Unfortunately, most of the farmers of our country often overlook to maintain an optimum $\mathrm{S}$ level in their field; even sometimes, they are confused with $\mathrm{S}$ deficiency symptoms with $\mathrm{P}$ or $\mathrm{N}$ deficiencies or $\mathrm{Al}$ toxicity. It is worthy to mention that the critical level of sulphur for Bangladesh soil has been determined as $10 \mu \mathrm{g}$ $\mathrm{g}^{-1}$ soil. To obtain higher yield, farmers currently use excess amount of gypsum, ammonium sulphate, zinc sulphate, etc. as sulphur fertilizers to the soils to replenish sulphur deficiency but it is not a good practice for the soils as well as environments in the long run. However, farmers of Bangladesh transplant rice seedlings without maintaining the optimum level of $\mathrm{S}$. Therefore, the present study was undertaken to study the effect of different levels of $S$ on nutrient uptake by BRRI dhan 41 and to find out the optimum level of sulphur for profitable rice production.

\section{Materials and Methods}

Experimental Site, Design and Management Practices

The experiment was conducted at the Soil Science Field Laboratory of Bangladesh Agricultural University, Mymensingh, during July to December 2007. Thirty days old seedlings of BRRI dhan41, a high yielding variety of rice, was transplanted in experimental field with the spacing of $20 \mathrm{~cm}$ x $20 \mathrm{~cm}$. The seedlings were collected from a rice seedbed. The experiments were comprised of eight treatments including control (Table 1). The experiment was laid out in a randomized complete block design (RCBD) with three replications. Each replication was sub-divided into eight unit plots. The treatments were randomly distributed to the unit plots therefore the total numbers of plots were 24. The unit plot size was $4 \mathrm{~m} x$ $2.5 \mathrm{~m}$. The distance between plot-to-plot and replication to replication were 0.25 and $0.50 \mathrm{~m}$, respectively. Gap filling was done with the even aged seedling within two weeks after transplanting. The full doses of TSP, MOP, gypsum and zinc oxide were applied according to treatments as a source of $\mathrm{P}, \mathrm{K}, \mathrm{S}$ and $\mathrm{Zn}$ as $\mathrm{kg} \mathrm{ha}^{-1}$ before transplanting (Table 1). Urea was applied as a source of $\mathrm{N}\left(\mathrm{kg} \mathrm{ha}^{-1}\right)$ in three equal splits as per treatments. The first split of urea was applied after 12 days of transplanting, the second split was applied as top dressing after 30 days of transplanting and third split was applied after 58 days of transplanting. Irrigation, weeding and other cultural management practices were done whenever necessary.

\section{Data Collection}

Soil properties: Initial soil sample was collected before land preparation from the plough depth layer (0$15 \mathrm{~cm})$. The samples were taken by means of an auger from different locations covering the whole experimental plot and mixed thoroughly to make a composite sample. The composite samples were then air dried, pulverized, sieved and used for chemical analysis to determine the soil health in terms of different physical (percentage of sand, silt, clay, and textural class) and chemical properties (soil pH, soil organic carbon, total nitrogen, available phosphorous, exchangeable potassium, CEC and available sulfur) (Table 2). The soil analysis for the above parameters was done by using the following methods:

Physical properties: Among physical properties, percentage of sand, silt, clay, and textural class was determined by Hydrometer method as described by Bouyoucos, 1962.

Chemical properties: Soil $\mathrm{pH}$ was measured by Glass Electrode $\mathrm{pH}$ meter method with soil- water ratio being maintained at 1: 2.5 (McLean, 1982).

Organic matter: At first organic carbon (\%) in soil sample was determined by wet oxidation method of Walkley and Black (1934) and then it was converted into organic matter (\%) multiplying by 1.72 (Edwards et al., 1999) conversion factor.

Total nitrogen: Total nitrogen content of soil was determined by Kjeldahl Method following concentrated sulphuric acid digestion and steam distillation with $40 \%$ $\mathrm{NaOH}$. The ammonia evolved was collected in a beaker containing $4 \%$ boric acid with an indicator composed of 95\% alcohol, methyl red and bromocresol green and was titrated against $0.02 \mathrm{~N} \mathrm{H}_{2} \mathrm{SO}_{4}$ as described by Jackson (1973).

Exchangeable potassium: Exchangeable potassium was extracted with neutral $1 \mathrm{~N} \quad \mathrm{NH}_{4} \mathrm{OAc}(\mathrm{pH}$ 7) as described by Jackson (1973) and was measured by Atomic Absorption Spectrophotometer (Model No. 17030, HITACHI, Japan) and readings were calibrated with a standard K curve (Page et al., 1982).

Available phosphorous: Extraction for available phosphorous in the soil samples was made with $0.5 \mathrm{M}$ $\mathrm{NaHCO}_{3}$ solution at a nearly constant $\mathrm{pH}$ of 8.5 following the method described by Olsen et al. (1954). Spectrophotometer (660 nm wave length) was used to measure the intensity of the colour developed by ascorbic acid method as outlined by John (1970) and readings were calibrated with a standard P curve (Page et al., 1982).

Available sulfur (ppm): Available sulfur was determined turbidimetrically according to Bardsley and Lancaster (1965).

\section{Plant Samples}

Plant samples for instance grain and straw were collected from the field and dried in an oven at about $65^{\circ} \mathrm{C}$ for 48 hours. Then the samples grinded properly and the grinded materials were stored in small paper bags and placed in desiccators. The grain and straw samples were the analyzed for the determination of $\mathrm{N}, \mathrm{P}, \mathrm{K}$ and $\mathrm{S}$ by using following methods:

Total nitrogen (\%): Total nitrogen contents were determined by modified Kjeldajl digestion (colorimetric) method (Cataldo et. al., 1974).

Total Phosphorus (P), potassium (K), Sulphur (S) content in plant (\%): Oven-dried plant materials were digested with concentrated $\mathrm{HNO}_{3}$ and $\mathrm{HCLO}_{4}$ mixture as described by Piper (1966) for determination of P, K, S content both in grain and straw samples.

After chemical analysis of straw and grain samples, the nutrient uptake was calculated from the nutrient 
content and yield of rice crop by using the following formula as described by Sharma et al. (2012).

$$
\mathrm{NU}=\frac{\mathrm{NC} \times \text { Yield }\left(\mathrm{kg} \mathrm{ha}^{-1}\right)}{100}
$$

Where;

$\mathrm{NU}=$ Nutrient uptake,

$\mathrm{NC}=$ Nutrient content $(\%)$

\section{Growth and Yield Contributing Characters}

Ten plants were randomly selected from each unit plot for collection of data on the following parameters viz. plant height $(\mathrm{cm})$, panicle length $(\mathrm{cm})$, filled grains per panicle, grain yield $\left(\mathrm{t} \mathrm{ha}{ }^{-1}\right)$, straw yield $\left(\mathrm{kg} \mathrm{ha}^{-1}\right)$ and biological yield $\left(\mathrm{t} \mathrm{ha}^{-1}\right)$.

\section{Statistical Analysis}

Finally, the data was analyzed by using statistical package program (MSTAT-C). The analysis of variance for crop characters and for the nutrient content and nutrient uptake by the grain and straw were done following by the Duncan's Multiples Range Test (DMRT) (Gomez and Gomez, 1984).

\section{Results and Discussion}

The Growth and Yield Contributing Characters

The plant height of BRRI dhan41 was not significantly affected by the application of different levels of sulphur. The effect of different levels of $S$ on plant height was inconsistent (Table 3). The highest value $(120.5 \mathrm{~cm})$ was recorded in the treatment $\mathrm{T}_{1}(50 \%$ RFD of $\mathrm{S})$, the second highest value $(118.8 \mathrm{~cm})$ was recorded in the treatment $\mathrm{T}_{3}(100 \%$ RFD of $\mathrm{S})$, while the lowest plant height $(113.8 \mathrm{~cm})$ was found in the control treatment $\left(\mathrm{T}_{0}\right)$. All treatments produced statistically similar plant height. The results also indicated that addition of $\mathrm{S}$ applied insignificant effect on plant height. There was a significant effect due to the application of different levels of $S$ on the production of effective tillers per hill of BRRI dhan41 (Table 3). The number of effective tillers per hill due to different treatments varied from 7.87 to 9.33 . The highest number of effective tillers per hill (9.33) was found in the treatment $\mathrm{T}_{5}(150 \%$ RFD of $\mathrm{S})$ which was statistically similar to those recorded in the treatments $\mathrm{T}_{7}$ (200\% RFD of S) and $\mathrm{T}_{3}(100 \%$ RFD of $\mathrm{S}$ ) with the values of 9.20 and 9.07. The treatment $\mathrm{T}_{0}$ (control) produced the lowest number of effective tillers per hill (7.87). It indicated that $S$ application at higher rates over the recommended dose has significant effect on the number of effective tillers per hill. An increase in the number of tillers per hill due to application of $\mathrm{S}$ was also reported by several workers (Patra et al., 1998 and Chandel et al., 2002). Panicle length of BRRI dhan41 was not significantly influenced by different treatments (Table 3). The length of panicle varied from $22.83 \mathrm{~cm}$ to 24.20 $\mathrm{cm}$. The highest panicle length $(24.20 \mathrm{~cm})$ was observed in $\mathrm{T}_{1}(50 \% \mathrm{RFD}$ of $\mathrm{S})$ treatment. The lowest panicle length of $22.83 \mathrm{~cm}$ was recorded in the treatment $\mathrm{T}_{0}$ (control). All treatments produced statistically similar panicle length. Apostol (1989) observed that organic and in organic fertilizers increased the panicle length of rice. Similar results were also found by Ahmed and Rahaman (1991). Results presented in the Table 3 showed a significant effect of different $S$ levels on the number of filled grains per panicle of BRRI dhan41. The number of filled grains per panicle due to different treatments ranged from 98.00 to 135.6. The highest number of filled grains per panicle (135.6) was obtained from the treatment $\mathrm{T}_{1}$ (50\% RFD of S). The lowest number (98.00) of filled grains per panicle was obtained from the treatment $\mathrm{T}_{0}$ (control). The significant effects of $\mathrm{S}$ application on the number of grains per panicle were also reported by Hque and Chowdhury (2004). The positive responses of sulphur application on the number of grains per panicle were also reported by Uddin et al. (1997). There was significant effect on 1000 grain weight of BRRI dhan41 by the application of different levels of sulphur fertilizer. The 1000 grain weight varied from 27.16 to $29.30 \mathrm{gm}$ (Table 3 ). The maximum 1000 grain weight ( $29.30 \mathrm{~g}$ ) was found in treatment $\mathrm{T}_{3}(100 \%$ RFD of $\mathrm{S})$ and minimum (27.16 g) value was obtained in the treatment $\mathrm{T}_{0}$ (control). Choudhury and Bodiuzzaman (1992) reported that sulphur fertilizer increased the 1000 grain weight.

Table 1 Treatments and fertilizer doses used in the study

\begin{tabular}{|c|c|c|c|c|c|c|}
\hline \multirow{2}{*}{ Treatments } & \multirow{2}{*}{ Treatment combination } & \multicolumn{5}{|c|}{ Fertilizer dose $(\mathrm{kg} / \mathrm{ha})$} \\
\hline & & $\mathrm{N}$ & $\mathrm{P}$ & $\mathrm{K}$ & $\mathrm{S}$ & $\mathrm{Zn}$ \\
\hline $\mathrm{T}_{\mathrm{o}}$ & $\mathrm{S}_{0 \text { (control) }}+\mathrm{RFD}$ of NPKZn & 90 & 15 & 40 & 0 & 2 \\
\hline $\mathrm{T}_{1}$ & $\mathrm{~S}_{(50 \% \text { RFD of s })}+$ RFD of NPKZn & 90 & 15 & 40 & 5 & 2 \\
\hline $\mathrm{T}_{2}$ & $\mathrm{~S}_{(75 \% \text { RFD of s) }}+$ RFD of NPKZn & 90 & 15 & 40 & 7.5 & 2 \\
\hline $\mathrm{T}_{3}$ & $\mathrm{~S}_{(100 \% \mathrm{RFD} \text { of } \mathrm{s})}+$ RFD of NPKZn & 90 & 15 & 40 & 10 & 2 \\
\hline $\mathrm{T}_{4}$ & $\mathrm{~S}_{(125 \% \mathrm{RFD} \text { of s })}+\mathrm{RFD}$ of NPKZn & 90 & 15 & 40 & 12.5 & 2 \\
\hline $\mathrm{T}_{5}$ & $\mathrm{~S}_{(150 \% \text { RFD of s })}+$ RFD of NPKZn & 90 & 15 & 40 & 15 & 2 \\
\hline $\mathrm{T}_{6}$ & $\mathrm{~S}_{(175 \% \mathrm{RFD} \text { of s })}+\mathrm{RFD}$ of NPKZn & 90 & 15 & 40 & 17.5 & 2 \\
\hline $\mathrm{T}_{7}$ & $\mathrm{~S}_{(200 \% \text { RFD of s })}+$ RFD of NPKZn & 90 & 15 & 40 & 20 & 2 \\
\hline
\end{tabular}

Source: BARC, 2005. RFD= Recommended Fertilizer Dose 
Table 2 Physical and chemical characteristics of the initial soil

\begin{tabular}{|c|c|}
\hline Physical Characteristics & Value \\
\hline Particle size analysis & \\
\hline$\%$ of sand & 20.4 \\
\hline$\%$ of silt & 68.0 \\
\hline$\%$ of clay & 11.6 \\
\hline Textural class & Silt loam \\
\hline Chemical Characteristics & \\
\hline $\mathrm{pH}$ (Soil: water $=1: 2.5)$ & 6.15 \\
\hline Organic matter $(\%)$ & 2.29 \\
\hline CEC (me $100 g^{-1}$ soil) & 13.78 \\
\hline Total N $(\%)$ & 0.1863 \\
\hline Available $\mathrm{P}(\mathrm{ppm})$ & 7.89 \\
\hline Exchangeable K (me100 g ${ }^{-1}$ soil) & 0.13 \\
\hline Available S (ppm) & 10.73 \\
\hline Critical level of S (ppm) in soil & 10 \\
\hline
\end{tabular}

Table 3 Effect of different levels of $\mathrm{S}$ on the growth and yield contributing characters of BRRI dhan41

\begin{tabular}{l|ccccccccccc}
\hline Treatment & PH & ET & PL & FG & GW & GY & IC & SY & IC & BY & IC \\
\hline $\mathrm{T}_{0}$ & 113.8 & $7.87^{\mathrm{b}}$ & 22.83 & $98.00^{\mathrm{a}}$ & $27.16^{\mathrm{c}}$ & $3.72^{\mathrm{d}}$ & - & $4.69^{\mathrm{e}}$ & - & 8.41 & - \\
$\mathrm{T}_{1}$ & 120.5 & $8.45^{\mathrm{ab}}$ & 24.20 & $135.6^{\mathrm{a}}$ & $28.44^{\mathrm{ab}}$ & $4.76^{\mathrm{b}}$ & 21.85 & $6.10^{\mathrm{d}}$ & 18.69 & 10.86 & 22.56 \\
$\mathrm{~T}_{2}$ & 118.2 & $8.87^{\mathrm{ab}}$ & 23.97 & $128.4^{\mathrm{ab}}$ & $27.24^{\mathrm{c}}$ & $4.43^{\mathrm{c}}$ & 16.40 & $6.33^{\mathrm{bc}}$ & 25.91 & 10.76 & 21.84 \\
$\mathrm{~T}_{3}$ & 118.8 & $9.07^{\mathrm{a}}$ & 23.30 & $129.0^{\mathrm{ab}}$ & $29.30^{\mathrm{a}}$ & $4.55^{\mathrm{bc}}$ & 18.24 & $6.30^{\mathrm{cd}}$ & 25.56 & 10.85 & 22.49 \\
$\mathrm{~T}_{4}$ & 115.6 & $8.40^{\mathrm{ab}}$ & 23.00 & $112.7^{\mathrm{ab}}$ & $29.25^{\mathrm{a}}$ & $4.48^{\mathrm{c}}$ & 16.96 & $6.67^{\mathrm{a}}$ & 29.69 & 11.15 & 24.57 \\
$\mathrm{~T}_{5}$ & 115.2 & $9.33^{\mathrm{a}}$ & 23.03 & $115.1^{\mathrm{ab}}$ & $27.72^{\mathrm{bc}}$ & $4.52^{\mathrm{bc}}$ & 17.70 & $6.60^{\mathrm{a}}$ & 28.94 & 11.12 & 24.37 \\
$\mathrm{~T}_{6}$ & 118.6 & $8.67^{\mathrm{ab}}$ & 24.07 & $132.3^{\mathrm{a}}$ & $27.62^{\mathrm{bc}}$ & $5.22^{\mathrm{a}}$ & 28.74 & $6.53^{\mathrm{ab}}$ & 28.18 & 11.75 & 28.43 \\
$\mathrm{~T}_{7}$ & 118.6 & $9.20^{\mathrm{a}}$ & 23.77 & $121.6^{\mathrm{ab}}$ & $28.79^{\mathrm{a}}$ & $5.08^{\mathrm{a}}$ & 26.77 & $6.63^{\mathrm{a}}$ & 29.26 & 11.71 & 28.18 \\
$\mathrm{CV}(\%)$ & 3.41 & 6.77 & 3.80 & 13.42 & 1.68 & 3.01 & - & 1.91 & - & - & - \\
$\mathrm{SE}( \pm)$ & $\mathrm{NS}$ & 0.3416 & NS & 9.419 & 0.2739 & 0.07958 & - & 0.2072 & - & - & - \\
\hline
\end{tabular}

PH: Plant height (cm); ET: Effective tillers/ hill (no.); PL: Panicle length (cm); FG: Filled grains/ panicle (no.); GW: 1000 grain weight (g); GY: Grain Yield (t/ha); IC: \% Increase over control; SY: Straw Yield (t/ha); BY: Biological Yield (t/ha); Different letters within the column indicate statistically significant differences between treatments according to Duncan's Multiples Range Test (DMRT) $(\mathrm{P}<0.05)$. Letters were not shown in columns, which were statistically non-significant. Values are means \pm SE of three independent replications $(n=3)$.

\section{Grain and Straw Yield}

Data on grain and straw yields of BRRI dhan 41 as affected by different $\mathrm{S}$ application are presented in Table 3. Results in Table 3 showed that grain yield of BRRI dhan41 was significantly influenced due to different treatments. The grain yield due to various treatments ranged from 3.72 to $5.22 \mathrm{t} / \mathrm{ha}$. The highest grain yield (5.22 $\mathrm{t} / \mathrm{ha})$ was obtained in the treatment $\mathrm{T}_{6}(175 \%$ RFD of $\mathrm{S})$. The lowest grain yield (3.72 t/ha) was obtained in the treatment $\mathrm{T}_{0}$ (control) which was statistically different from all other treatments. The increase in grain yield over control ranged from 16.40 to $28.74 \%$ (Table 3 ). The highest percentage $(28.74 \%)$ of increased grain yield over control was recorded in the treatment $\mathrm{T}_{6}(175 \%$ RFD of S). The lowest percentage $(16.40 \%)$ of increased grain yield over control was recorded in the treatment $\mathrm{T}_{2}(75 \%$ RFD of S). Deng et al. (1992) observed $23.9 \%$ yield increase of rice due to application of $S$ as gypsum. Bhuiya and Portch (1992) also reported the superiority of gypsum over SSP as S source. Gupta and Soi (1992) reported that gypsum increased grain yield of rice by $28 \%$ over control. The present findings are in agreement with the results of the previous study. Tandon (1995), Gupta et al. (1996), Oliveira et al. (2003) who reported increased yield of rice due to sulphur application irrespective of $S$ source and rates. Similar results were also reported by Islam et al. (1996) and Raju and Reddy (2001). Results presented in the Table 3 show that straw yield of BRRI dhan41 was significantly influenced by different treatments under study. The straw yield obtained from different treatments ranged between 4.69 to $6.67 \mathrm{t} / \mathrm{ha}$. All the treatments gave higher straw yield over control. It was observed that the treatment $\mathrm{T}_{4}(125 \%$ RFD of $\mathrm{S})$ gave the highest straw yield (6.67 t/ha) which was statistically similar to those recorded in the treatment $\mathrm{T}_{7}(200 \%$ RFD of $\mathrm{S})$ and $\mathrm{T}_{5}(150 \%$ RFD of $\mathrm{S})$ with value of 6.63 and 6.60. The lowest straw yield $(4.69 \mathrm{t} / \mathrm{ha})$ was recorded in the treatment $\mathrm{T}_{0}$ (control). The percent increase of straw yield over control ranged from 18.69 to $29.69 \%$ and the highest and lowest value was recorded in the treatment $\mathrm{T}_{4}$ (125\% RFD of S) and $\mathrm{T}_{1}(50 \%$ RFD of $\mathrm{S})$ respectively. The straw yield due to different treatments ranked in the order of $\mathrm{T}_{4}>\mathrm{T}_{7}>\mathrm{T}_{5}>\mathrm{T}_{6}>\mathrm{T}_{2}>\mathrm{T}_{3}>\mathrm{T}_{1}>\mathrm{T}_{0}$. The results revealed that the application of higher dose of sulphur exerted pronounced effect in producing higher straw yields of rice. It also indicates that application of $\mathrm{S}$ fertilizer at rates higher than the recommended dose significantly increased the straw yield of BRRI dhan 41 . Hoque and Khan (1981), Idris and Jahiruddin (1983), Tapatkar and Sonar (1995) reported that S application significantly increased the straw yield of rice. Table 3 shows that biological yield of BRRI dhan41 responded significantly. The biological yield varied widely among the treatments, ranging from 8.41 to $11.75 \mathrm{t} / \mathrm{ha}$. The 
highest biological yield (11.75 t/ha) was obtained in the treatment $\mathrm{T}_{6}(175 \%$ RFD of $\mathrm{S})$. The lowest biological yield $(8.41 \mathrm{t} / \mathrm{ha})$ was obtained in the treatment $\mathrm{T}_{0}$ (control). The increase in biological yield over control ranged from 22.56 to $28.43 \%$ (Table 3 ). The highest percentage $(28.43 \%)$ of increased biological yield over control was recorded in the treatment $\mathrm{T}_{6}(175 \%$ RFD of S) and the lowest percentage $(22.56 \%)$ of increased biological yield over control was recorded in the treatment $\mathrm{T}_{1}(50 \%$ RFD of $\mathrm{S})$. The biological yield obtained from different treatments ranked in order of $\mathrm{T}_{6}>\mathrm{T}_{7}>\mathrm{T}_{4}>\mathrm{T}_{5}>\mathrm{T}_{1}>\mathrm{T}_{3}>\mathrm{T}_{2}>\mathrm{T}_{0}$. The results revealed that the application of higher dose of $\mathrm{S}$ on the biological yield of rice was more pronounced than that of other treatment under study. Azim et al. (1999) reported a significant increase in biological yield of rice due to application of fertilizer.

\section{Nutrient Content and Uptake by Grain and Straw}

The grain and straw samples of BRRI dhan41 were analyzed for the determination of $\mathrm{N}, \mathrm{P}, \mathrm{K}$ and $\mathrm{S}$ contents and the nutrient uptake was calculated from the yield and nutrient concentration of grain and straw. Data presented in Table 4 indicate that the various treatments had significant influence on $\mathrm{N}$ content in grain and straw of BRRI dhan41. Nitrogen nutrition and metabolism in plants is intimately associated with the sulphur status and their metabolic process (Abdallah et al., 2010). However, the $\mathrm{N}$ content in grain ranged from $1.16 \%$ to $1.25 \%$. The highest $\mathrm{N}$ content $(1.25 \%)$ in grain was found in treatment $\mathrm{T}_{7}(200 \%$ RFD of $\mathrm{S})$. The lowest $\mathrm{N}$ content $(1.16 \%)$ in grain was observed in treatment $\mathrm{T}_{0}$ (control). In the case of straw, the $\mathrm{N}$ content ranged from $0.90 \%$ to $1.03 \%$ (Table 4). The highest $\mathrm{N}$ content $(1.03 \%)$ was recorded in treatment $\mathrm{T}_{5}(150 \%$ RFD of $\mathrm{S})$ which was statistically identical with the treatments $\mathrm{T}_{7}(200 \%$ RFD of $\mathrm{S}), \mathrm{T}_{6}$ (175\% RFD of S), $\mathrm{T}_{4}(125 \%$ RFD of $\mathrm{S}), \mathrm{T}_{2}(75 \%$ RFD of S) and $\mathrm{T}_{1}(50 \% \mathrm{RFD}$ of $\mathrm{S})$ with values of $0.98 \%, 0.95 \%$, $0.93 \%, 0.93 \%$ and $0.95 \%$ respectively. As expected the lowest $\mathrm{N}$ concentration $(0.90 \%)$ in straw was observed in the treatment $\mathrm{T}_{0}$ (control). The higher amount of $\mathrm{N}$ in grain in compare to straw might be attributable to translocation of the $\mathrm{N}$ occur from vegetative part to the reproductive organ or senescence of leaves. Corroborate findings also found by Sachdev et al. (1983) on rice. Results in Table 4 show a wide variation in $\mathrm{N}$ uptake by grain and straw due to different treatments. The nitrogen uptake by rice grain ranged from 43.22 to $63.32 \mathrm{~kg} / \mathrm{ha}$. The highest amount of $\mathrm{N}$ uptake $(63.32 \mathrm{~kg} / \mathrm{ha})$ by grain was observed in the treatment $\mathrm{T}_{7}(200 \%$ RFD of $\mathrm{S})$ which was statistically different from other treatments. The lowest amount of $\mathrm{N}$ uptake $(43.22 \mathrm{~kg} / \mathrm{ha})$ by grain was observed in treatment $\mathrm{T}_{0}$ (control). In case of straw, the nitrogen uptake ranged from $41.34 \mathrm{~kg} / \mathrm{ha}$ to $68.41 \mathrm{~kg} / \mathrm{ha}$. The highest nitrogen uptake by rice straw was recorded in $\mathrm{T}_{7}(200 \%$ RFD of S) which was statistically similar with the treatment $\mathrm{T}_{5}(150 \%$ RFD of $\mathrm{S}$ ) with the value of 68.10 $\mathrm{kg} / \mathrm{ha}$. The lowest amount of $\mathrm{N}$ uptake $(41.34 \mathrm{~kg} / \mathrm{ha})$ by straw was observed in treatment $\mathrm{T}_{0}$ (control). The total nitrogen uptake by grain and straw of BRRI dhan 41 ranged from $84.56 \mathrm{~kg} / \mathrm{ha}$ to $131.7 \mathrm{~kg} / \mathrm{ha}$. The highest amount of total $\mathrm{N}$ uptake (131.7 $\mathrm{kg} / \mathrm{ha})$ was observed in treatment $\mathrm{T}_{7}(200 \%$ RFD of $\mathrm{S})$ which was statistically identical with the treatments $\mathrm{T}_{6}(175 \%$ RFD of $\mathrm{S})$, with the value of $126.7 \mathrm{~kg} / \mathrm{ha}$. The lowest amount of total $\mathrm{N}$ uptake $(84.56 \mathrm{~kg} / \mathrm{ha})$ was recorded in treatment $\mathrm{T}_{0}$ (control). The total nitrogen uptake by BRRI dhan41 due to different treatments ranked in order of $\mathrm{T}_{7}>\mathrm{T}_{6}>\mathrm{T}_{5}>\mathrm{T}_{4}>$ $\mathrm{T}_{1}>\mathrm{T}_{2}>\mathrm{T}_{3}>\mathrm{T}_{0}$. The higher $\mathrm{N}$ uptake might be associated with exploration of greater soil volume by root exacerbated by sulphur application (Mandal et al., 2003). More precisely we can say that root represent a portion of aerial biomass, which greatly heighten in response to $S$ fertilization. The concomitant increase of root biomass allowing capturing of more $\mathrm{N}$ from the soil, and thus increasing $\mathrm{N}$ uptake by the plant (Salvagiotti et al., 2009). Furthermore, synergism between $\mathrm{N}$ and $\mathrm{S}$ also ameliorate $\mathrm{N}$ uptake (Shamima and Imamul Hug, 2002; Salvagiotti et al., 2009). The result is in consistent with the result of Singh and Singh (2002), Sharma and Gangwar (1997) who noted that $\mathrm{N}$ uptake in rice plant increased with increasing rates of $\mathrm{S}$ application.

Data in Table 4 showed that the $\mathrm{P}$ content in grain and straw of rice (var. BRRI dhan41) varied significantly due to the application of different doses of sulphur fertilizer. Phosphorus content in grain varied from $0.22 \%$ to $0.30 \%$. The highest amount of $\mathrm{P}$ concentration $(0.30 \%)$ was found in the treatments $\mathrm{T}_{6}(175 \%$ RFD of $\mathrm{S})$ and $\mathrm{T}_{1}(50 \%$ RFD of $S$ ), which was statistically identical with the treatments $\mathrm{T}_{5}(150 \%$ RFD of $\mathrm{S}), \mathrm{T}_{4}(125 \%$ RFD of $\mathrm{S}), \mathrm{T}_{3}$ (100\% RFD of $\mathrm{S}), \mathrm{T}_{2}$ (75\% RFD of $\mathrm{S}$ ) and $\mathrm{T}_{0}$ (control), with the values of $0.28 \%, 0.28 \%, 0.28 \%, 0.25 \%$ and $0.24 \%$, respectively. The lowest amount of $\mathrm{P}$ concentration $(0.22 \%)$ in grain was found in the treatment $\mathrm{T}_{7}(200 \%$ RFD of $\mathrm{S})$. In case of straw, there was a significant effect of various treatments on $\mathrm{P}$ content in straw (Table 4). The $\mathrm{P}$ content in straw ranged from 0.08 to $0.14 \%$. The highest amount of $\mathrm{P}$ concentration $(0.14 \%)$ in straw was observed in the treatment $\mathrm{T}_{1}(50 \%$ RFD of S) which was statistically different from other treatments. The lowest amount of $\mathrm{P}$ concentration $(0.08 \%)$ was recorded in the treatment $\mathrm{T}_{2}(75 \% \mathrm{RFD}$ of $\mathrm{S})$. The result indicated that $\mathrm{P}$ content in grain increased by the application of S. It also indicated that the concentration of phosphorus in grain is always higher than that of straw. Padihar et al. (1985) reported that phosphorus content in grain was increased with increasing level of $S$ application. Phosphorus uptake by grain and straw was significantly influenced due to application of different levels of sulphur (Table 4). Phosphorus uptake by the grain of BRRI dhan 41 by grain ranged from 9.20 to $15.48 \mathrm{~kg} / \mathrm{ha}$. The highest amount of $\mathrm{P}$ uptake $(15.48 \mathrm{~kg} / \mathrm{ha})$ by grain was recorded in the treatment $\mathrm{T}_{6}(175 \%$ RFD of $\mathrm{S})$. The lowest amount of $\mathrm{P}$ uptake $(9.20 \mathrm{~kg} / \mathrm{ha})$ by grain was observed in the treatment $\mathrm{T}_{0}$ (control). The $\mathrm{P}$ uptake by straw of BRRI dhan41 ranged from 5.02 to $8.33 \mathrm{~kg} / \mathrm{ha}$ (Table 4$)$. The highest amount of P uptake $(8.33 \mathrm{~kg} / \mathrm{ha})$ by straw was found in the treatment $\mathrm{T}_{1}(50 \% \mathrm{RFD}$ of $\mathrm{S})$ which was statistically identical with the treatment $\mathrm{T}_{5}$ (150\% RFD of S) with the value of 7.70 . The lowest 
amount of P uptake $(5.02 \mathrm{~kg} / \mathrm{ha})$ by straw was observed in the treatment $\mathrm{T}_{0}$ (control). The total phosphorus uptake by grain and straw varied from 14.22 to $22.47 \mathrm{~kg} / \mathrm{ha}$ due to different treatments. The highest amount of total $\mathrm{P}$ uptake $(22.47 \mathrm{~kg} / \mathrm{ha})$ was found in treatment $\mathrm{T}_{1}(50 \%$ RFD of S) which was statistically similar with the treatment $\mathrm{T}_{6}$ (175\% RFD of $S$ ) with the value of 22.45 . The lowest amount of total $\mathrm{P}$ uptake $(14.22 \mathrm{~kg} / \mathrm{ha})$ was obtained in $\mathrm{T}_{0}$ (control). The total $\mathrm{P}$ uptake due to different treatments ranked in the order of $\mathrm{T}_{1}>\mathrm{T}_{6}>\mathrm{T}_{5}>\mathrm{T}_{4}>\mathrm{T}_{3}>\mathrm{T}_{7}>\mathrm{T}_{2}>\mathrm{T}_{0}$.

Potassium content in grain and straw of rice was significantly influenced due to different levels of $\mathrm{S}$ application (Choudhury and Badiuzzaman, 1992). The potassium content in grain varied from 0.206 to $0.240 \%$ (Table 5). The highest amount of $\mathrm{K}$ concentration $(0.240 \%)$ in grain was observed in $\mathrm{T}_{1}(50 \%$ RFD of $\mathrm{S})$ which was statistically different from all other treatments. The lowest amount of $\mathrm{K}$ concentration $(0.206 \%)$ in grain was found in the $\mathrm{T}_{2}(75 \%$ RFD of $\mathrm{S})$. On the other hand, $\mathrm{K}$ concentration in straw ranged from 2.10 to $2.83 \%$. The highest amount of $\mathrm{K}$ concentration $(2.83 \%)$ in straw was observed in $\mathrm{T}_{7}(200 \%$ RFD of $\mathrm{S})$ which was statistically identical with the treatments $\mathrm{T}_{6}(175 \%$ RFD of $\mathrm{S}), \mathrm{T}_{4}$ (125\% RFD of S), $\mathrm{T}_{3}(100 \%$ RFD of $\mathrm{S}), \mathrm{T}_{2}(75 \%$ RFD of S) and $\mathrm{T}_{1}(50 \% \mathrm{RFD}$ of $\mathrm{S})$ with the values of $2.68 \%$, $2.63 \%, 2.63 \%, 2.73 \%$, and $2.73 \%$, respectively. The lowest amount of $\mathrm{K}$ concentration $(2.10 \%)$ in straw was found in $\mathrm{T}_{5}(150 \% \mathrm{RFD}$ of $\mathrm{S})$. The results indicated that the $\mathrm{K}$ uptake by grain and straw of rice (var. BRRI dhan41) was also significantly influenced by the different treatments (Table 5). Dobermann and Fairhust (2000) also found the same results with the increasing of $\mathrm{S}$ level $\mathrm{K}$ content and $\mathrm{K}$ concentration was increased in rice grain and straw. The $\mathrm{K}$ uptake by rice grain varied from 7.82 to $11.48 \mathrm{~kg} / \mathrm{ha}$. The highest amount of $\mathrm{K}$ uptake (11.48 $\mathrm{kg} / \mathrm{ha})$ by grain was recorded in the treatment $\mathrm{T}_{6}(175 \%$ RFD of $\mathrm{S}$ ) which was statistically similar with the treatment $\mathrm{T}_{1}(50 \%$ RFD of $\mathrm{S})$ with the value of 11.42 $\mathrm{kg} / \mathrm{ha}$. The lowest amount of $\mathrm{K}$ uptake $(7.82 \mathrm{~kg} / \mathrm{ha})$ by grain was observed in $\mathrm{T}_{0}$ (control). Potassium uptake by straw ranged from 108.1 to $187.7 \mathrm{~kg} / \mathrm{ha}$. The highest amount of $\mathrm{K}$ uptake $(187.7 \mathrm{~kg} / \mathrm{ha})$ by straw was observed in treatment $\mathrm{T}_{7}(200 \%$ RFD of S) which was statistically similar with the treatments $\mathrm{T}_{6}(175 \%$ RFD of $\mathrm{S}), \mathrm{T}_{4}$ (125\% RFD of $\mathrm{S}), \mathrm{T}_{3}(100 \%$ RFD of $\mathrm{S}), \mathrm{T}_{2}$ (75\% RFD of S) and $\mathrm{T}_{1}(50 \%$ RFD of $\mathrm{S})$ with the values of 174.8 , 175.3, 165.2, 172.7 and 166.6 respectively. On the other hand the lowest amount of $\mathrm{K}$ uptake $(108.1 \mathrm{~kg} / \mathrm{ha})$ by straw was obtained in the treatment $\mathrm{T}_{0}$ (control). The results also revealed that $\mathrm{K}$ uptake by straw was higher than that by grain.

Table 4 Effect of different levels of S on the Nitrogen and Phosphorus of BRRI dhan41

\begin{tabular}{l|cccccccccc}
\hline Treatment & NCG & NCS & NUG & NUS & TNU & PCG & PCS & PUG & PUS & TPU \\
\hline $\mathrm{T}_{0}$ & $1.16^{\mathrm{g}}$ & $0.90^{\mathrm{b}}$ & $43.22^{\mathrm{d}}$ & $41.34^{\mathrm{c}}$ & $84.56^{\mathrm{d}}$ & $0.24^{\mathrm{ab}}$ & $0.10^{\mathrm{c}}$ & $9.20^{\mathrm{d}}$ & $5.02^{\mathrm{e}}$ & $14.22^{\mathrm{e}}$ \\
$\mathrm{T}_{1}$ & $1.19^{\mathrm{e}}$ & $0.95^{\mathrm{ab}}$ & $56.30^{\mathrm{b}}$ & $57.96^{\mathrm{b}}$ & $114.3^{\mathrm{c}}$ & $0.30^{\mathrm{a}}$ & $0.14^{\mathrm{a}}$ & $14.13^{\mathrm{ab}}$ & $8.33^{\mathrm{a}}$ & $22.47^{\mathrm{a}}$ \\
$\mathrm{T}_{2}$ & $1.20^{\mathrm{d}}$ & $0.93^{\mathrm{ab}}$ & $53.18^{\mathrm{c}}$ & $58.70^{\mathrm{b}}$ & $111.9^{\mathrm{c}}$ & $0.25^{\mathrm{ab}}$ & $0.08^{\mathrm{f}}$ & $11.10^{\mathrm{cd}}$ & $5.06^{\mathrm{e}}$ & $16.17^{\mathrm{de}}$ \\
$\mathrm{T}_{3}$ & $1.17^{\mathrm{f}}$ & $0.88^{\mathrm{b}}$ & $53.27^{\mathrm{c}}$ & $55.46^{\mathrm{b}}$ & $108.7^{\mathrm{c}}$ & $0.28^{\mathrm{ab}}$ & $0.10^{\mathrm{d}}$ & $12.60^{\mathrm{bc}}$ & $6.08^{\mathrm{cd}}$ & $18.68^{\mathrm{bc}}$ \\
$\mathrm{T}_{4}$ & $1.19^{\mathrm{e}}$ & $0.93^{\mathrm{ab}}$ & $53.19^{\mathrm{c}}$ & $61.85^{\mathrm{ab}}$ & $115.0^{\mathrm{c}}$ & $0.28^{\mathrm{ab}}$ & $0.10^{\mathrm{d}}$ & $12.37^{\mathrm{bc}}$ & $6.46^{\mathrm{cd}}$ & $18.83^{\mathrm{bc}}$ \\
$\mathrm{T}_{5}$ & $1.22^{\mathrm{c}}$ & $1.03^{\mathrm{a}}$ & $55.02^{\mathrm{bc}}$ & $68.10^{\mathrm{a}}$ & $123.1^{\mathrm{b}}$ & $0.28^{\mathrm{ab}}$ & $0.12^{\mathrm{b}}$ & $12.48^{\mathrm{bc}}$ & $7.70^{\mathrm{ab}}$ & $20.18^{\mathrm{ab}}$ \\
$\mathrm{T}_{6}$ & $1.24^{\mathrm{b}}$ & $0.95^{\mathrm{ab}}$ & $64.56^{\mathrm{a}}$ & $62.11^{\mathrm{ab}}$ & $126.7^{\mathrm{ab}}$ & $0.30^{\mathrm{a}}$ & $0.11^{\mathrm{c}}$ & $15.48^{\mathrm{a}}$ & $6.97^{\mathrm{bc}}$ & $22.45^{\mathrm{a}}$ \\
$\mathrm{T}_{7}$ & $1.25^{\mathrm{a}}$ & $0.98^{\mathrm{ab}}$ & $63.32^{\mathrm{a}}$ & $68.41^{\mathrm{a}}$ & $131.7^{\mathrm{a}}$ & $0.22^{\mathrm{b}}$ & $0.09^{\mathrm{e}}$ & $11.17^{\mathrm{cd}}$ & $5.74^{\mathrm{de}}$ & $16.92^{\mathrm{cd}}$ \\
$\mathrm{CV}(\%)$ & 0.70 & 6.44 & 2.89 & 6.25 & 3.73 & 11.79 & 8.41 & 11.86 & 7.98 & 6.98 \\
$\mathrm{SE}( \pm)$ & 0.0001826 & 0.03651 & 0.9227 & 2.138 & 2.468 & 0.01826 & 0.0001826 & 0.8434 & 0.2955 & 0.7556 \\
\hline
\end{tabular}

NCG: N content\% in grain; NCS: N content\% in straw; NUG: N uptake (kg/ha) in grain; NUS: N uptake (kg/ha) in straw; TNU: Total N uptake (kg/ha); PCG: P content\% in grain; PCS: P content\% in straw; PUG: P uptake $(\mathrm{kg} / \mathrm{ha})$ in grain; PUS: P uptake ( $\mathrm{kg} / \mathrm{ha})$ in straw; TPU: Total P uptake (kg/ha); Different letters within the column indicate statistically significant differences between treatments according to Duncan's Multiples Range Test (DMRT) $(\mathrm{P}<0.05)$. Letters were not shown in columns, which were statistically non-significant. Values are means $\pm \mathrm{SE}$ of three independent replications $(\mathrm{n}=3)$.

Table 5 Effect of different levels of S on the Potassium and Sulphur of BRRI dhan41

\begin{tabular}{l|llllllllll}
\hline Treatment & KCG & KCS & KUG & KUS & TKU & SCG & SCS & SUG & SUS & TSU \\
\hline $\mathrm{T}_{0}$ & $0.210 \mathrm{~d}$ & $2.30 \mathrm{bc}$ & $7.82 \mathrm{e}$ & $108.1 \mathrm{c}$ & $115.9 \mathrm{c}$ & $0.144 \mathrm{c}$ & $0.158 \mathrm{c}$ & $5.36 \mathrm{c}$ & $7.42 \mathrm{e}$ & $12.78 \mathrm{c}$ \\
$\mathrm{T}_{1}$ & $0.240 \mathrm{a}$ & $2.73 \mathrm{ab}$ & $11.42 \mathrm{a}$ & $166.6 \mathrm{a}$ & $178.0 \mathrm{a}$ & $0.175 \mathrm{a}$ & $0.142 \mathrm{f}$ & $8.34 \mathrm{a}$ & $8.67 \mathrm{de}$ & $17.02 \mathrm{ab}$ \\
$\mathrm{T}_{2}$ & $0.206 \mathrm{e}$ & $2.73 \mathrm{ab}$ & $9.16 \mathrm{~d}$ & $172.7 \mathrm{a}$ & $181.8 \mathrm{a}$ & $0.134 \mathrm{e}$ & $0.124 \mathrm{~g}$ & $5.92 \mathrm{bc}$ & $7.85 \mathrm{de}$ & $13.78 \mathrm{c}$ \\
$\mathrm{T}_{3}$ & $0.210 \mathrm{~d}$ & $2.63 \mathrm{ab}$ & $9.56 \mathrm{~cd}$ & $165.2 \mathrm{a}$ & $174.7 \mathrm{ab}$ & $0.132 \mathrm{~g}$ & $0.143 \mathrm{e}$ & $6.01 \mathrm{bc}$ & $8.99 \mathrm{~cd}$ & $15.00 \mathrm{bc}$ \\
$\mathrm{T}_{4}$ & $0.210 \mathrm{~d}$ & $2.63 \mathrm{ab}$ & $9.42 \mathrm{~d}$ & $175.3 \mathrm{a}$ & $184.8 \mathrm{a}$ & $0.122 \mathrm{~h}$ & $0122 \mathrm{~h}$ & $5.44 \mathrm{c}$ & $8.12 \mathrm{de}$ & $13.55 \mathrm{c}$ \\
$\mathrm{T}_{5}$ & $0.230 \mathrm{~b}$ & $2.10 \mathrm{c}$ & $10.39 \mathrm{bc}$ & $138.4 \mathrm{~b}$ & $148.8 \mathrm{~b}$ & $0.167 \mathrm{~b}$ & $0.156 \mathrm{~d}$ & $7.56 \mathrm{ab}$ & $10.29 \mathrm{bc}$ & $17.85 \mathrm{a}$ \\
$\mathrm{T}_{6}$ & $0.220 \mathrm{c}$ & $2.68 \mathrm{ab}$ & $11.48 \mathrm{a}$ & $174.8 \mathrm{a}$ & $186.2 \mathrm{a}$ & $0.140 \mathrm{~d}$ & $0.162 \mathrm{~b}$ & $7.34 \mathrm{ab}$ & $10.60 \mathrm{ab}$ & $17.94 \mathrm{a}$ \\
$\mathrm{T}_{7}$ & $0.210 \mathrm{~d}$ & $2.83 \mathrm{a}$ & $10.67 \mathrm{ab}$ & $187.7 \mathrm{a}$ & $198.4 \mathrm{a}$ & $0.133 \mathrm{f}$ & $0.178 \mathrm{a}$ & $6.76 \mathrm{abc}$ & $11.81 \mathrm{a}$ & $18.57 \mathrm{a}$ \\
$\mathrm{CV}(\%)$ & 4.10 & 9.07 & 4.82 & 9.49 & 9.07 & 12.86 & 8.85 & 13.90 & 8.56 & 8.43 \\
$\mathrm{SE}( \pm)$ & 0.0001826 & 0.1354 & 0.2781 & 8.823 & 8.962 & 0.0001826 & 0.0001826 & 0.5288 & 0.4557 & 0.7690 \\
\hline
\end{tabular}

KCG: K content\% in grain; KCS: K content\% in straw; KUG: K uptake (kg/ha) in grain; KUS: K uptake (kg/ha) in straw; TKU: Total K uptake (kg/ha); SCG: S content\% in grain; SCS: S content\% in straw; SUG: S uptake (kg/ha) in grain; SUS: S uptake (kg/ha) in straw; TSU: Total S uptake (kg/ha); Different letters within the column indicate statistically significant differences between treatments according to Duncan's Multiples Range Test $(\mathrm{DMRT})(\mathrm{P}<0.05)$. Letters were not shown in columns, which were statistically non-significant. Values are means $\pm \mathrm{SE}$ of three independent replications $(\mathrm{n}=3)$. 
In general, potassium uptake by leaf and petiole increased up to reproductive stage and decreased at maturity level, which implies that translocation of potassium to developed grain (Shamima and Imamul Hug, 2002). Uptake of potassium by stem, on the other hand is associated with increased of stem dry matter. It is worthy to mention that the stem served as a largest reservoir for potassium throughout the growth cycle. Nevertheless, we found contrasting result as higher potassium in straw and lower in grain. This result what we found might be due to the uptake potassium by the above ground part is mostly translocate to root instead of grain for their profuse growth to facilitate higher $\mathrm{N}$ uptake. This is phenomenon is termed as luxury consumption or overconsumption (Saleque et al., 1998). Kabir et al. (2011) support the findings of our study. Total potassium uptake by grain and straw varied from $115.9 \mathrm{~kg} / \mathrm{ha}$ to $198.4 \mathrm{~kg} / \mathrm{ha}$. The highest amount of total K uptake $(198.4 \mathrm{~kg} / \mathrm{ha})$ was found in treatment $\mathrm{T}_{7}(200 \%$ RFD of $\mathrm{S}$ ) which was statistically similar with the treatments $\mathrm{T}_{6}(175 \%$ RFD of $\mathrm{S}), \mathrm{T}_{4}$ (125\% RFD of S), $\mathrm{T}_{2}$ (75\% RFD of $\mathrm{S}$ ) and $\mathrm{T}_{1}(50 \% \mathrm{RFD}$ of $\mathrm{S})$ with the values of $186.2,184.8,181.8$ and 178.0 respectively. The lowest amount of total $\mathrm{K}$ uptake (115.9 $\mathrm{kg} / \mathrm{ha}$ ) was observed in $\mathrm{T}_{0}$ (control). The total $\mathrm{K}$ uptake due to different treatments can be ranked in the order of $\mathrm{T}_{7}>\mathrm{T}_{6}>\mathrm{T}_{4}>\mathrm{T}_{2}>\mathrm{T}_{1}>\mathrm{T}_{3}>\mathrm{T}_{5}>\mathrm{T}_{0}$.

Sulphur content in grain and straw of rice was significantly influenced due to different levels of $\mathrm{S}$ application. The $\mathrm{S}$ concentration in grain ranged from 0.122 to $0.175 \%$ (Table 5). The critical level of $S$ in rice straw and grain is $0.5 \%$ (Mukit, 2009). The highest amount of $\mathrm{S}$ concentration $(0.175 \%)$ in grain was obtained in the treatment $\mathrm{T}_{1}(50 \%$ RFD of $\mathrm{S})$ which was statistically different from all other treatments. The lowest amount of S concentration $(0.122 \%)$ in grain was found in the $\mathrm{T}_{4}(125 \%$ RFD of $\mathrm{S})$. On the other hand, $\mathrm{S}$ content in straw varied from 0.122 to $0.178 \%$ (Table 4.6). The highest $S$ concentration $(0.178 \%)$ was observed in treatment $\mathrm{T}_{7}(200 \%$ RFD of $\mathrm{S})$ which was statistically different from all other treatments. The lowest amount of $\mathrm{S}$ concentration in straw $(0.122 \%)$ was found in $\mathrm{T}_{4}(125 \%$ RFD of $\mathrm{S}$ ). The results indicated that $\mathrm{S}$ content in grain and straw increased by the application of higher rates of $\mathrm{S}$. It also indicated that $\mathrm{S}$ content in grain is greater than that of straw. Chandel et al. (2002) observed concentration of $S$ in rice plant increased with increasing rates of $S$ application. Result in Table 5 indicated that the $\mathrm{S}$ uptake by grain and straw of rice was significantly influenced by the different treatments. Sulphur uptake by grain varied from 5.36 to $8.34 \mathrm{~kg} / \mathrm{ha}$. The highest amount of $\mathrm{S}$ uptake $(8.34 \mathrm{~kg} / \mathrm{ha})$ by grain was observed in the treatment $\mathrm{T}_{1}(50 \%$ RFD of $\mathrm{S})$ which was statistically identical with the treatments $\mathrm{T}_{6}(175 \%$ RFD of $\mathrm{S})$ and $\mathrm{T}_{5}$ (150\% RFD of $\mathrm{S}$ ) with the values of 7.34 and 7.56 respectively. The lowest $S$ uptake $(5.35 \mathrm{~kg} / \mathrm{ha})$ by grain was observed in $\mathrm{T}_{0}$ (control) treatment. Sulphur uptake by straw varied from 7.42 to $11.81 \mathrm{~kg} / \mathrm{ha}$. The highest amount of $\mathrm{S}$ uptake $(11.81 \mathrm{~kg} / \mathrm{ha})$ by straw was recorded in treatment $\mathrm{T}_{7}(200 \%$ RFD of S) which was statistically identical with the treatment $\mathrm{T}_{6}(175 \%$ RFD of $\mathrm{S})$ with the value 10.60. The lowest amount of $\mathrm{S}$ uptake $(7.42 \mathrm{~kg} / \mathrm{ha})$ by straw was obtained in $\mathrm{T}_{0}$ (control). The total $\mathrm{S}$ uptake by grain and straw ranged from 12.78 to $18.57 \mathrm{~kg} / \mathrm{ha}$. The highest amount of total $\mathrm{S}$ uptake $(18.57 \mathrm{~kg} / \mathrm{ha})$ was observed in treatment $\mathrm{T}_{7}(200 \%$ RFD of $\mathrm{S})$ which was statistically similar with the treatments $\mathrm{T}_{6}(175 \%$ RFD of $\mathrm{S})$ and $\mathrm{T}_{5}(150 \%$ RFD of $\mathrm{S})$ with the value of 17.94 and 17.85 , respectively. The lowest total $\mathrm{S}$ uptake (12.78 $\mathrm{kg} / \mathrm{ha}$ ) was observed in $\mathrm{T}_{0}$ (control). The total $\mathrm{S}$ uptake due to different treatments ranked the in order of $\mathrm{T}_{7}>\mathrm{T}_{6}>$ $\mathrm{T}_{5}>\mathrm{T}_{1}>\mathrm{T}_{3}>\mathrm{T}_{2}>\mathrm{T}_{4}>\mathrm{T}_{0}$. Sakal (1995) and Poongothi et al. (1999) reported that application of $S$ increased $S$ uptake by rice plant.

\section{Conclusions}

Deficiency of sulphur has become a great concern over the past decades in most of the agricultural areas of Bangladesh. Therefore, to replenish the nutrient deficiency, farmers use gypsum as a source of sulphur without knowing their perilous consequences to the soil. Optimum doses of sulphur along with its interaction effect with other nutrients is crucially needed for successful crop production. The results obtained from the present study demonstrated that different levels of sulphur fertilizer significantly influenced the growth and yield attributes of BRRI dhan41 rice variety. Among the growth characteristics, plant height and panicle length were not significantly influenced by $\mathrm{S}$ fertilization likewise number of effective tillers. On the other hand, yield attributes viz. number of filled grains per panicle, 1000-grain weight, biological yield and grain yield were considerably varied by different gradient of $\mathrm{S}$ fertilizers. Regarding nutrient analysis, in all cases, the highest amount of nutrients found in grain instead of straw except for potassium. Furthermore, nutrient uptake by grain and straw differed in different treatment. However, based on the above fact, in spite of different interaction effect with other nutrients, $\mathrm{T}_{6}(175 \%$ RFD of $\mathrm{S})$ treatments gave the highest yield might be due to the highest nutrient use efficiency. Therefore, further study with given priority to improvement of nutrient use efficiency with nutrient uptake should be conducted to boost yield of the new variety.

\section{Acknowledgement}

The study was funded by the Department of Soil Science, Bangladesh Agricultural University, Mymensingh, Bangladesh. The author likes to thank Head of the department and other concern personnel of the department for valuable guide and support.

\section{References}

Abdallah M, Dubousset L, Meuriot F, Etienne P, Avice JC, Ourry A. 2010. Effect of mineral sulphur availability on nitrogen and sulphur uptake and remobilization during the vegetative growth of Brassica napus L. Journal of Experimental Botany. 61(10): 2635-2646. 
Abdullah HM, Mahboob MG, Rahman MM, Ahmed T. 2015. Monitoring Natural Sal Forest Cover in Modhupur, Bangladesh using Temporal Landsat Imagery during 1972-2015. Int Environ. 5(1): 1-7.

Abdullah HM, Rahman MM. 2015. Initiating rainwater harvest technology for climate change induced drought resilient agriculture: scopes and challenges in Bangladesh. Journal of Agriculture and Environment for International Development 109: 189-208.

Ahmed M, Rahman S. 1991. Influence of organic matter on the yield and mineral nutrition of modern rice and soils properties. Bangladesh Rice J. 2(1-2): 107-112.

Akhter S, Ali MI, Jahiruddin M, Ahmed S, Rahman L. 1994. Main and interaction effects of sulphur and zinc on rice. Crop Res. (Hisar.). 7(1): 1-7.

Apostol EDF. 1989. Influence of mineral organic and X-rice liquid fertilizer in combination with inorganic fertilizer on IR66 and BPIRi12 rice varieties. Malabben, Metro Manila, Philippines: 73.

Azim SMA, Rahman MM, Islam MR, Hoque MA. 1999. Effect of S, Zn and B on BRRI dhan 29 M. S. Thesis, Dept. Soil Sci. Bangladesh Agricultural University, Bangladesh.

Bardsley CE, Lancaster JD. 1965. Sulphur. In: C.A. Black et al. Methods of Soil Analysis. Agronomy 9, Part 2. American Society of Agronomy. Madison. Wisconsin, pp. 1102-1116.

BBS (Bangladesh Bureau of Statistics). 2013. Monthly Statistical Bulletin of Bangladesh. Bangladesh Bureau of Statistics. Stat. Div., Ministry of Planning. Gov. Peoples Repub. Bangladesh, Dhaka. p. 254.

BBS, 2010. Hand Book of Agriculture Statistics, Bangladesh Bureau of Statistics. <http://www.bbs.gov.bd/>. (accessed on 20.01.12).

Bera M, Ghosh GK. 2015. Efficacy of sulphur sources on green gram (Vigna radiata 1 .) in red and lateritic soil of West Bengal. International Journal of Plant, Animal and Environmental Sciences. 5(2): 109-116.

Bhuiyan, NI, Portch S. 1992. Sulphur fertilization for rice and nonrice crops of Bangladesh Agriculture. In Proc. Int. Symp. On the role of sulphur, magnesium and micronutrients in balanced plant nutrition. pp. 81-93.

Bouyoucos GJ. 1962. Hydrometer method improved for making particle size analysis of soils. Agron. J. 54: 461-465.

BRRI (Bangladesh Rice Research Institute). 2011. Adhunik Dhaner Chash (in bengali). Bangladesh Rice Research Institute, Joydebpur, Gazipur. p: 5.

Cataldo DA, Schrader LE, Youngs VL. 1974. Analysis by digestion and colorimetric assay of total nitrogen in plant tissues high in $\begin{array}{llll}\text { nitrate. } & \text { Crop } & \text { Science. } & \text { 14: }\end{array}$ http://dx.doi.org/10.2135/cropsci1974.0011183X001400060024 $\mathrm{x}$.

Chandel RS, Sudhakar PC, Kalyan, Singh. 2002. Effect of sulphur application on growth and yield of rice in rice-mustard cropping sequence. Crop Research Hisar. 24(2): 261-265.

Choudhury FA, Badiuzzaman. 1992. Effect of different levels of potash and sulphur on the growth and yield of Pajam rice. Bangladesh J. Agril. Sci. 19 (1): 37-40.

Deng XW, Matsui M, Wei N, Wagner D, Chu AM, Feldmann KA, Quail PH. 1992. COP1, an Arabidopsis regulatory gene, encodes a protein with both a zinc-binding motif and a $\mathrm{G}$ beta homologous domain. Cell 71: 791-801.

Dobermann A, Fairhust T. 2000. Rice: Nutrient Disorders \& Nutrient management. IRRI. Phillipines, PPI, USA., PPIC, Canada.

Edwards JH, Wood CW, Thurlow DL, Ruf ME. 1999. Tillage and crop rotation effects on fertility status of a Hapludalf soil. Soil Sci. Soc. Am. J. 56:1577-1582.

FAO F. 2013. Statistical Yearbook. World Food and Agriculture. Food and Agriculture Organization of the United Nations, Rome. pp: 289.

Gomez KA, Gomez AK. 1984. Statistical procedure for Agricultural Research. 2nd ed. John Wiley and Sons. New York. : 207-215.
Gupta JP, Soi ATR. 1992. Effect of gypsum application on physicochemical characteristics of sodic soil and crop yield of rice (Oryza sativa) and wheat (Triticum aestivum). Indian J. Agron. 37 (4): 812-814.

Gupta P, Shakya SK, Kumar D, Singh J. 1996. Effect of different doses of gypsum on soil properties and crop yield under drained conditions. Dept. Soil and Water Engr. Punjab Agril. Univ. Indian. Annuals of Biology, Ludiaua. 12(1): 157-162.

Haque SA, Chawdhury L. 2004. Effects of rice straw and sulphur on the growth and yield of rice. J. Bangladesh Agril. Univ. 2(1): 518.

Hoefgen R, Nikiforova VJ. 2008. Metabolomics integrated with transcriptomics: assessing systems response to sulfur-deficiency stress. Physiol. Plant. 132: 190-198.

Hoque MZ, Khan MAH. 1981. Role of higher nitrogen rate, sulphur and zinc application in bridging the yield gap of farmer's boro rice in Bangladesh. Int. Rice. Res. Newsl. 6(4): 20.

Huq I, Shoaib JU. 2013. The Soils of Bangladesh. Springer Dordrecht Heidelberg New York London. Pp. 60.

Idris M, Jahiruddin M. 1983. Response of BR3 Rice to Sulphur fertilization. Int. Rice Comm. Newsl. XXX II (1): 28-29.

Islam AKMS, Nath, UK, Rai PK, Rahman MM, Haque MA, Rahman MA. 2016. Genetic study and selection of soybean lines for higher yield. Int. J. Biosci. 8(2): 209-217.

Islam M, Hoque MA, Reza MM, Rahman MM. 2015. Contribution of boron doses on growth and yield of different broccoli genotypes. Int. J. Sustain. Crop Prod. 10(2): 14-20.

Islam MR, Karim MR, Rasat TM, Jahiruddin M. 1996. Growth and yield of BR11 rice under different levels of S, Zn and B fertility at two locations in Bangladesh. Thai J. Agric. Sci. 29: 37-42.

Jackson ML. 1973. Soil Chemical Analysis. Pentice Hall of India Pvt. Ltd., New Delhi.

John MK. 1970. Colorimetric determination of phosphorus in soil and plant materials with ascorbic acid. Soil Science 109: 214220.

Kabir MH, Talukder NM, Uddin MJ, Mahmud H, Biswas BK. 2011. Total nutrient uptake by grain plus straw and economic of fertilizer use of rice mutation STL-655 grown under Boro season in saline area. J. Environ. Sci. \& Natural Resources, 4(2): 83-87.

Mandal UK, Singh G, Victor US, Sharma KL, 2003. Green manuring: its effect on soil properties and crop growth under rice-wheat cropping system. European Journal of Agronomy 19: 225-237.

McLean EO. 1982. Soil pH and lime requirement. In Page, A. L., R. H. Miller and D. R. Keeney (eds.) Methods of soil analysis. Part 2-Chemical and microbiological properties. (2nd Ed.). Agronomy 9:199-223.

Mukit MR. 2009. Agri-Carrier book. Soil Science Part. pp: 129-132. Oliveira SC, Costa MCG, Chamas RC, Cabral CP, Malavolta E. 2003. Response of two rice rates of Zinc applied as oxysulphate. Pesquisa. Agropecuaria, Brasibira. 38(3): 387-396.

Olsen S, Cole C, Watanabe F, Dean L. 1954. Estimation of available phosphorus in soils by extraction with sodium bicarbonate. USDA Circular Nr 939, US Gov. Print. Office, Washington, D.C.

Padihar SK, Dikshit PR. 1985. Nutrient composition and yield of rice at different levels of phosphorus and moisture. Oryza India, 22: $17-22$.

Page AL, Miller RH, Keeney DR. 1982. Methods of Soil Analysis. 2nd Edn., Amercen Society of Agronomy, Madison, WI., USA.

Patra PK, Nenu HU, Goswami NN. 1998. Influence of sulphur application and water management practices on sulphur nutrition, growth and yield of rice in some sulphur deficient wet land rice soils. Oryza. 35 (2): 135-139.

Piper CS. 1966. Soil Plant Analysis. Hans Publishers, Bombay.

Poongothi S, Savithri P, Vennila RK, Biju. 1999. Influence of gypsum and green leaf manure application on rice. J. Indian Soc. Soil Sci. 47(1): 96-99. 
Prosser IM, Purves JV, Saker LR, Clarkson DT. 2001. Rapid disruption of nitrogen metabolism and nitrate transport in spinach plants deprived of sulphate. Journal of Experimental Botany 52: 113-121.

Raju RA, Reddy MN. 2001. Response of hybrid and conventional rice to Gliricidia loppings, sulphur and zinc application. Fertilizer News. 46 (11): 61-62.

Sachdev MS, Mittal RB, Sachdev P. 1983. Utilization of sulphur by rice from gypsum and its balance sheet in soil using S-35. J. Nucl. Agric. Biol. 6(1): 11-14.

Sakal R. 1995. Soil sulphur deficiencies and crop responses to sulphur in Bihar, India Sulphur in Agriculture. Sulphur Institute, Washington D.C.

Saleque MA, Saha PK, Panaullah GM, Bhuiyan NI. 1998. Response of wetland rice to potassium in farmers' fields of the Barind tract of Bangladesh. J Plant Nutri 21: 39-47.

Salvagiotti F, Castellarín JM, Miralles DJ, Pedrol HM. 2009. Sulfur fertilization improves nitrogen use efficiency in wheat by increasing nitrogen uptake. Field Crops Research, 113(2): 170177.

Shamima N, Imamul Hug SM. 2002. Effect of sulphur fertilizer on yield and nutrient uptake of sunflower crop in an Albaquept soil. Pakistan J. Biological Sciences. 5(5): 533-536.

Sharma NK, Singh RJ, Kumar K. 2012. Dry matter accumulation and nutrient uptake by Wheat (Triticum aestivum L.) under Poplar (Populus deltoides) based agroforestry system. Agronomy. Article ID 359673. http://dx.doi.org/ 10.5402/2012/35967.

Sharma YK, Gangwar MS. 1997. Distribution of different forms of sulphur and their relationship with some soil properties in Alfisols, Inceptisols and Mollisols of Moradabad district, Uttar Pradesh. J. Indian Soc. Soil Sci. 45 (3): 480-485.
Singh CS, Singh UN. 2002. Effects of nitrogen and sulphur nutrition on growth and yield of rice (Oryza sativa L.) cultivars Res. On Crops. 3(3): 643-646.

Sohel MH, Miah MR, Mohiuddin SJ, Islam AKMS, Rahman MM, Haque MA. 2016. Correlation and path coefficient analysis of Blackgram (Vigna mungo L.). J. Biosci. Agric. Res. 07(02): 621-629. doi: 10.18801/jbar.070216.74.

Tandon HLS. 1995. Fertilizer Development and Consultant Organization. New Delhi, India. Sulphur in Indian Agriculture. Sulphur Institute, Washington, D.C.

Tapatkar P, Sonar KR. 1995. Effect of pyrite on release of Fe, P and $\mathrm{S}$ in a calcareous Inceptisols and yield of rice. J. Indian Soc. Soil Sci. 43(4): 696-698.

Tewari RK, Kumar P, Sharma PN. 2010. Morphology and oxidative physiology of sulphur-deficient mulberry plants. Environmental and Experimental Botany. 68: 301-308.

Uddin MN, Islam MR, Hossain A. 1997. Effects of nitrogen, phosphorus and sulphur on aus rice and their residual effect of aman rice in a tidal flooded soil of Bangladesh. Bangladesh $\mathrm{J}$. Agric. Sci., 24(1): 61-65.

Walkley A, Black IA. 1934. An examination of the Degtjareff method for determining soil organic matter and a proposed modification of the chromic acid titration method. Soil Science, 37: 29-38.

World Bank, 2013. Turn down the heat: climate extremes, regional impacts, and the case for resilience. A report for the World Bank by the Potsdam Institute for climate impact research and climate analytics. World Bank, Washington, D.C. 